\title{
Security of the Person and Deportation to Torture
}

\section{Kristine Para}

According to Greene (2014), "about 90 percent of all Charter arguments raised in reported cases across all Canadian courts deal with one of the legal rights [in] sections 7-14" (p. 198). The prevalence of cases that rely on section 7 alone are either to raise additional arguments or to raise a Charter challenge (Greene, 2014, p. 198). In the Charter of Rights and Freedoms, section 7 guarantees that "everyone has the right to life, liberty, and security of person." While this section includes three types of provisions, this essay will focus particularly on the right to security of the person. It is worth examining who can be protected and what circumstances a violation may be justified, since Canadian case laws have presented varying positions around that subject matter. The judicial interpretations of section 7 are often inconsistent with precedents, and such interpretations are essentially affected by state interests.

Stewart (2012) explains that, "in determining whether s. 7 applies, [courts] must look at the interests at stake rather than the legal label attached to the legislation" (p. 72). In the context of national security, this becomes problematic for the individual because courts will often prioritize Canada's security over the legalities of section 7 . These extreme instances demand Canadian officials to respond on the basis of "refoulement," meaning that the accused individuals are forced to return to a country where they are likely to face torture (Jenkins, 2009, p. 159). A prime example of refoulement was in 2002, when a dual Syrian and Canadian citizen named Maher Arar was returning to Canada from a family vacation in Tunisia (Jenkins, 2009, p. 151). The RCMP assumed that Arar's vacation was a cover up for his involvement in terrorist activities, and according to the Canadian Bar Association (2017), it was the "RCMP's decision to provide raw information to U.S. authorities about [his] suspected al-Qaeda affiliation" (p. 6). Consequently, Arar was detained at the John F. Kennedy International Airport during his layover, and he was later deported to Syria where he endured torture for over a year (Jenkins, 2009, p.151). However, later investigations proved that Arar had no affiliation with al-Qaeda or any terrorist activities in general (Jenkins, 2009, p. 151). While the RCMP and U.S. authorities should have conducted a thorough investigation prior to deporting Arar to Syria, academics say it was likely that the lingering anxiety from 9/11 prompted them to act swiftly on their suspicion (Johnston, 2011, p.10).

With Arar's story, it is interesting to consider how valued section 7 is in Canada-a country known for its multicultural values and utmost respect for human rights. Canada's devotion to advocate for such values is embodied by upholding the "standard achievement for all peoples and all nations" set out in the Universal Declaration of Human Rights (U.D.H.R.) (Corbett \& Sadoway, 2016, p. 102). Precisely, the right to security of the person in section 7 of the Charter comes directly from Article 3 in the U.D.H.R. (Corbett \& Sadoway, 2016, p. 102). Canada appears to hold an earnest moral obligation to protect all individuals from physical harm and the emotional distress that comes from anticipating such, but this is not always the case for non-citizens under Canada's immigration laws (Corbett \& Sadoway, 2016, p. 39; p. 102). In the context of refoulement, the progression of case laws concerning section 7 demonstrates that 


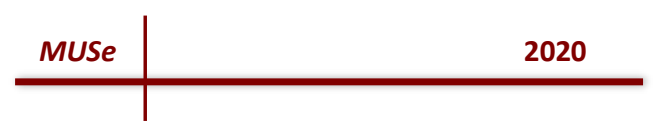

Canada's judicial system offers limited protection for refugees. Particularly, those who are in most need of protection are often rejected from such opportunities.

In the 1985 Singh v. Minister of Employment and Immigration case, Satnam Singh applied for Convention refugee status in Canada because he had reasonable grounds to believe that he would be at imminent danger if he were deported (para. 6-7). To specify, those who qualify as Convention refugees "are in need of protection because they have a well-founded fear of persecution in the country they are fleeing" (Greene, 2014, p. 202). The Refugee Status Advisory Committee did not have an updated version of the list of "refugee-producing countries" at the time they processed Singh's application, which significantly affected the outcome of his status (Greene, 2014, p. 202). The committee advised the Minister of Employment and Immigration that it was unlikely for Singh to face persecution, causing the Minister to deny his application and have him deported (Greene, 2014, p. 203). The Charter issue raised in Singh $v$. Minister of Employment and Immigration (1985) was to determine whether the procedure for asylum seekers conformed with the principles of fundamental justice, and whether refugees are also entitled to the protection provided in section 7 of the Charter (para. 1).

Fortunately, the Supreme Court ruled that the procedure was "inconsistent with the requirements of fundamental justice" for several reasons (Singh, 1985, para. 79). The justices of the Supreme Court of Canada defended that Singh was not given an adequate opportunity to respond to the information that caused his application to be rejected (Singh, 1985, para. 58). Specifically, it was unjust that he did not have the opportunity to "neither examine the minister's evidence nor to have an oral hearing" (Greene, 2014, p. 202). The justices also reasoned that "[the term] 'everyone' in s. 7 is intended to encompass a broader class of persons than citizens and permanent residents... [it] includes every human being who is physically present in Canada" (Singh, 1985, para. 35). Lastly, the justices established that "[to be] removed from Canada to a country where his life or freedom would be threatened...is a deprivation of security of the person within the meaning of s. 7" (Singh, 1985, para. 47). Following the Supreme Court's decision in Singh's case, Bill C-55 was introduced as a response (Greene, 2014, p. 207). Bill C-55 established the Immigration and Refugee Board to provide refugee applicants with a fair procedure, including an "oral hearing in front of a quasi-judicial panel" (Greene, 2014, p. 207). The Immigration and Refugee Board was also a strategy to prevent the refugee application process from being heavily guarded by the Charter, since the applications were sent to offices abroad (Greene, 2014, p. 207).

Thirteen years after Singh's case, Pushpanathan v. Canada (Minister of Citizenship and Immigration) (1998) further refined the refugee application process by establishing that the Immigration and Refugee Board must use a "standard of correctness" when reviewing decisions (para. 23). The purpose of issuing the "standard of correctness," as opposed to any other "standard of review," was to ensure that "the Board accurately [and comprehensively evaluated] all the criteria for refugee status" (Pushpanathan, 1998, para. 43; para. 47). In 1985, Veluppillai Pushpanathan successfully claimed Convention refugee status since he had reason to believe that he would be persecuted by Sri Lankan authorities (Pushpanathan, 1998, para. 2). While in Canada, Pushpanathan was arrested for drug trafficking which gave him eight years in federal prison (Pushpanathan, 1998, para. 3). Pushpanathan wanted to renew his claim for Convention refugee status, but following his arrest, Employment and Immigration Canada rejected his application and issued an order for deportation, as he was no longer considered a refugee 


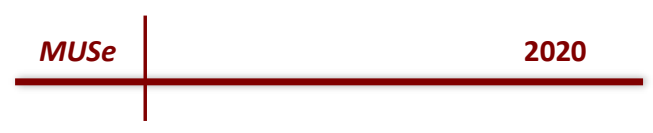

under Article 1F(c) in the United Nations Convention (Pushpanathan, 1998, para. 13). The key issue raised in Pushpanathan's case was whether drug trafficking should be included as a criterion in Article 1F(c), which is a significant clause in the United Nations Conventions that rejects an individual from seeking asylum in Canada (Pushpanathan, 1998, para. 17-18).

While the Federal Court rejected Pushpanathan's appeal, the Supreme Court recognized issues within Article $1 \mathrm{~F}(\mathrm{c})$ that conflicted with the principles of fundamental justice and the right to security of the person. The justices of the Supreme Court reasoned that adding a specific criterion such as drug trafficking to Article $1 \mathrm{~F}(\mathrm{c})$ would "undermine the primary purpose of the [United Nations] Convention" (Pushpanathan, 1998, para. 59). Particularly, Article $1 \mathrm{~F}(\mathrm{c})$ is broad enough to ensure that the Board can use their knowledge and discretion as it applies to the given case (Pushpanathan, 1998, para. 59). The justices also compared the nature of Article $1 \mathrm{~F}(\mathrm{c})$ to the scope of other Articles within the Convention, and they concluded that "a non-political crime such as drug trafficking should not be included in Article 1F(c)" (Pushpanathan, 1998, para. 73). In future cases where the Board might deport a refugee to torture by excluding them under Article $1 \mathrm{~F}(\mathrm{c})$, the Supreme Court decided that a "standard of correctness" must be used when reviewing these instances (Pushpanathan, 1998, para. 155). The "standard of correctness" ensures that all relevant clauses and criteria within the United Nations Convention is thoroughly considered (Pushpanathan, 1998, para. 155; para. 42). Upon consideration, the "standard of correctness" also requires that the officials hold relative expertise about the specific issue at hand (Pushpanathan, 1998, para. 33).

In the 2002 case of Suresh v. Canada (Minister of Citizenship and Immigration), the Supreme Court provided a clear and definitive response to refoulement. Manickavasagam Suresh was given Convention refugee status in 1991 to escape persecution in Sri Lanka (Suresh, 2002, para. 1). In 1995, the Canadian Security Intelligence Services (C.S.I.S.) found that he was affiliated with an organization that was "alleged to engage in terrorist activity" (Suresh, 2002, para. 1). Under section 40.1 of the Immigration Act, Suresh was issued a deportation certificate, and he was not given an opportunity to review or respond to the case made against him (Suresh, 2002, para. 9-10; para. 16). Suresh brought several Charter issues to the Supreme Court. He argued that the words, "danger to the security of Canada" and "terrorism," which cost him his refugee status, were unconstitutionally vague (Suresh, 2002, para. 2). Additionally, he argued that he was not given an adequate opportunity to meet the case against him (Suresh, 2002, para. 16). He concluded that deportation to torture violates the principles of fundamental justice and section 7 in the Charter, and for this reason, he claimed that the process of deporting individuals who are at risk of torture should be abolished (Suresh, 2002, para. 17; para. 21).

The Supreme Court rejected all of Suresh's claims. The justices explained that the words "danger to the security of Canada" and "terrorism" were not unconstitutionally vague because they established justifiable conditions for deportation (Suresh, 2002, para. 82). Despite Suresh's rejection, the Supreme Court agreed that the procedure to raise claims about deportation certificates should include minimal safeguards (Jenkins, 2009, p. 159). The Supreme Court acknowledged that, in similar instances, the refugee who is at risk of refoulement should be able to know and meet the case against him (Suresh, 2002, para. 123). However, having this opportunity does not entitle future refugees to "a full oral hearing or a complete judicial process," rather, it just requires that they are treated more fairly than how 


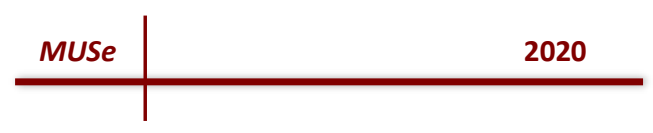

Suresh had been treated (Suresh, 2002, para. 121). The Supreme Court clarified that "deportation in and of itself does not [directly] engage section 7," thus, it would be illogical to abolish deportation certificates. (Stewart, 2012, p. 74). For Suresh's case, Said (2006) explains that, "in exceptional circumstances, deportation to torture might be justified" (p. 875). Every case is dealt with differently, and depending on the circumstances of those cases, the Supreme Court will balance refoulement with national security interests to their discretion (Said, 2006, p. 875). The court recognized that Suresh was at risk of torture if he were deported, however, upholding his section 7 rights could not be justified considering the threat he had on Canada's national security (Said, 2006, p. 875).

Furthermore, some academics find that courts have a relatively easier time defending Canadian citizens' section 7 rights, because such cases do not need to be balanced with state interests like national security (Heckman, 2017, p. 313; Said, 2006, p. 875). For example, in the case concerning access to abortion in $R$. v. Morgentaler, Chief Justice Dickson found that, "section 251 of the Criminal Code is prima facie a violation of the security of the person" (McDonald, 1989, p. 129). Greene (2014) further explains that, in this instance, a violation of section 7 is undisputed since the right to security of the person encompasses both the physical harm that women will endure from pregnancy through childbirth, and also the emotional distress from not wanting to carry a child (p. 229). On the other hand, Said (2006) describes that courts are less likely to consider section 7 violations for refugees accused of terrorism, despite the fact that these individuals undoubtedly face physical and emotional distress from refoulement ( $p$. 872). For instance, in Suresh's case, he was also at risk of enduring torture and emotional suffering, but the Supreme Court could not outweigh his section 7 rights over Canada's national security. (Said, 2006, p. 875). Overall, Heckman (2017) concludes that "in the refugee and immigration context, Canadian courts have adopted a narrow approach to the engagement of s. 7 that is inconsistent with their approach in the cognate areas of criminal law" (p. 313). These unparalleled interpretations exist because the Supreme Court is extremely cautious about setting precedence for cases that will negatively affect Canada's national security (Said, 2006, p. 881).

In some instances, Stewart (2012) explains that relying on section 7 can be advantageous due to the fact it uses "very general language" (p. 307). Unlike other sections of the Charter, this characteristic has made section 7 "the source for numerous constitutional claims that might be difficult to assert under other sections of the Charter" (Stewart, 2012, p. 307). However, to reiterate Heckman's (2017) comment, this characteristic is only beneficial for those making constitutional claims within the context of the Criminal Code (p. 313). In the case of $R v$. Ruzic (2001), Ruzic was charged for drug trafficking and was unable to use the defense of section 17 in the Criminal Code due to the court's interpretation of "duress" as defined in that section (Stewart, 2012, p. 194). Ruzic challenged the constitutionality of section 17 in the Criminal Code by arguing that her right to security of the person had been violated. Specifically, she endured extreme emotional distress by asserting that "the only way she could protect her mother was to obey [her perpetrator's] orders" (Ruzic, 2001, para. 7). Due to this claim, section 17 in the Criminal Code was subsequently "struck down" because it did not conform with the scope of section 7 (Stewart, 2012, p. 195). Comparably, Mohamed Harkat, a UN Convention refugee-who has been using section 7 to challenge the constitutionality of security certificates for almost two decades_-has yet to succeed in persuading the Supreme Court to make fair 


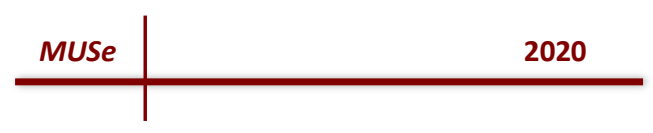

changes (Heckman, 2017, p. 328). To illustrate, security certificates are implemented in the Immigration and Refugee Protection Act (I.R.P.A.), and they are given to non-citizens who are subject to arbitrary confinement and refoulement (Heckman, 2017, p. 328).

While the broad language in section 7 offers some advantages for Canadian citizens, there appears to be numerous controversial issues for non-citizens. Oliphant (2015) asserts that, when it comes to non-citizens, "the Supreme Court's jurisprudence seems to push hard in the opposite direction, abjuring constraint and maximizing discretion" (p. 241). Precisely, the broad nature of section 7 is burdened in the hands of the Supreme Court, and their limitless discretion allows for inconsistencies. For example, "In Medovarski, the court held that deportation did not engage section 7 because 'non-citizens do not have an unqualified right to enter or remain in Canada"' (Stewart, 2012, p. 80). The problem is that earlier case laws, like Singh v. Minister of Employment and Immigration, established that the word "everyone" in section 7 included "non-citizens physically present in Canada" (Singh, 1985, para. 35). Accordingly, the overarching legislation has varying interpretations, and it does not necessarily guarantee that everyone has the right to such protection.

There are also issues with interpreting the meaning of "security." Academics like Rotman and Wydrzynski (2008) find that "many cases have grappled with the meaning of the phrase "life, liberty, and security of the person"' (p. 1105). In Mills v. The Queen (1986), "security" encompassed "stigmatization of the accused, loss of privacy, stress and anxiety resulting from a multitude of factors, including disruption of family, social life, and work" (para. 145). Comparably, this interpretation did not apply to Kanthasamy v. Canada (Citizenship and Immigration) (2015) when he applied for "humanitarian relief" under the Immigration and Refugee Act (para. 5). Kanthasamy described that he "fear[ed] for his safety after he was subjected to arbitrary detention and questioning by the Sri Lankan army" (Kanthasamy, 2015, para. 2). While Kanthasamy's (2015) case is explicitly a situation where one could argue for a section 7 violation, based on the interpretation of section 7 in Mills v. The Queen, the Immigration and Refugee Board refused Kanthasamy's claim (para. 3). The Board reasoned that they could not foresee any significant risks that he would face upon his return to Sri Lanka (Kanthasamy, 2015, para. 3). For this reason, Heckman (2017) argues that "courts should consistently apply the same principles to define the scope of...security of the person [for] citizens and non-citizens because these relate to our basic and common humanity" (p. 354).

Furthermore, some academics claim that the most controversial issue pertaining to section 7 is that it is not enough to completely renounce the inhumane practice of refoulement (Jenkins, 2009, p. 159). While Canada upholds itself as a country that is devoted to protecting human rights (Corbett \& Sadoway, 2016, p. 101), Jenkins (2009) argues that "[Canada has also] felt increasingly compelled to take extraordinary legal measures in protecting public safety and national security" (p. 158). These measures include "knowingly return[ing] an individual to a serious risk of torture," and there are currently no official alternatives to address these situations (Jenkins, 2009, p. 159). One explanation for why refoulement has not been absolutely prohibited in Canada might be due to the question of "whether Canada bears responsibility for that torture" (Jenkins, 2009, p. 130). Arguably, the torture that Maher Arar endured would not have happened if the RCMP or U.S. officials decided against his deportation (Jenkins, 2009, p. 151). Johnston (2011) explains that, "after $9 / 11$, the UN simultaneously called upon all states to bring justice to those involved in terrorist activity through the process of extradition" (p. 10). 


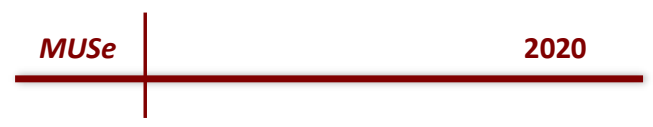

Hence, the practice of refoulement still remains because it is the recommended response in these kinds of situations (Johnston, 2011, p. 10). While section 7 attempts to protect the individual, the controversy around this legislation is that it may be easily restrained under concerns for national security.

In its immediacy, it seems easy to argue that Canada's national security comes before a single individual's right to feel secure. In another perspective, the balancing of scales might be far more difficult to do if the person at risk of deportation to torture is a close friend or family.

The overarching argument proposes that, by virtue of their humanity, citizens and noncitizens equally deserve the right to feel safe and secure from any form of harm. The case laws that were discussed in this essay demonstrate that safeguards were established for non-citizens over time, but to a limited extent. In Singh's case, Bill C-55, which created the Immigration and Refugee Board, makes it difficult for refugees to "invoke Charter rights in the first place" because their cases are sent abroad (Greene, 2014, p. 207). Refugee applications will not be restrained under the Charter, but in the event that they are mishandled, it is almost impossible to raise a case before the court (Greene, 2014, p. 207). In Pushpanathan's case, the "standard of correctness" is only applicable if the Supreme Court presents a different perspective than the Immigration and Refugee Board (McKee, 2016, p. 370). Furthermore, McKee (2016) explains that it is not likely for the Supreme Court to override the Immigration and Refugee Board's decision since the "standard of correctness" creates a consistent line of reasoning (p. 370). In Suresh's case, Canadian courts and policymakers were reluctant to establish legislation for refoulement, regardless of the fact that deportation to torture had already occurred in the past due to the lack of safeguards in place (Jenkins, 2009, p. 151).

In comparing how the right to security of the person was dealt with in the Criminal Code versus immigration law, it appears that courts tend to show more leniency for citizens than noncitizens. It is clear that there are far more significant interests at stake when dealing with noncitizens who are affiliated with terrorist activity, but by virtue of their humanity, those interests should not undermine anyone's right to life, liberty, or security. This is not to say that Canada's national security should be compromised by abolishing the idea of deportation, but there should be better alternatives to address state interests and the refugee's safety and right to security. Whether or not there is a lack of guilt due to the distance between Canadian authorities and the officials who commit the acts of torture overseas, every person who allows this act of violence to occur is part of an "abhorrent state practice" (Jenkins, 2009, p. 159). At the core of it all, deportation to torture is inhumane and the right to security of person should not only be considered but, rather, prioritized in these contexts. 


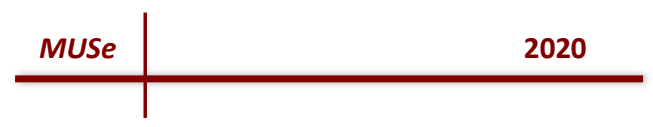

\section{References}

Canadian Bar Association. (2017) Security of Canada Information Sharing Act (SCISA). https://www.ourcommons.ca/Content/Committee/421/ETHI/Brief/BR8718954/brexternal/CanadianBarAssociation-e.pdf

Corbett, S. M., \& Sadoway, G. (2016). Canadian Human Rights Law \& Commentary. LexisNexis Canada.

Greene, I. (2014). The Charter of Rights and Freedoms: 30+ Years of Decisions That Shape Canadian Life. James Lorimer \& Company Ltd., Publishers

Heckman, G. (2017). "Revisiting the Application of Section 7 of the Charter in Immigration and Refugee Protection." University of New Brunswick Law Journal, 68, 312-356. Retrieved from https://library.macewan.ca/full-record/a9h/132191946

Jenkins, D. (2009). "Rethinking Suresh: Refoulement to Torture under Canada's Charter of Rights and Freedoms." Alberta Law Review, 47(1), 125-160. https://doi.org/10.29173/alr322

Johnston, J. G. (2011). "The Risk of Torture as a Basis for Refusing Extradition and the Use of Diplomatic Assurances to Protect against Torture after 9/11." International Criminal Law Review, 11(1), 1-48. https://doi.org10.1163/157181211x543911

Kanthasamy v. Canada (Citizenship and Immigration). (2015). 3 SCR 909 SCC 61. CanLII, https://canlii.ca/t/gmgsk

McDonald, D. C. (1989). Legal Rights in the Canadian Charter of Rights and Freedoms. Carswell

Mckee, D. (2016). "The Standard of Review for Questions of Procedural Fairness." Queen's Law Journal, 41(2), 355-407. Retrieved from EBSCOhost, https://library.macewan.ca/full-record/ofs/116094901

Mills v. The Queen. (1986). 1 SCR 863 SCC 17. Retrieved from CanLII, https://canlii.ca/t/1cxmx

Oliphant, B. J. (2015). "Taking Purposes Seriously: The Purposive Scope and Textual Bounds of Interpretation Under the Canadian Charter of Rights and Freedoms." The University of Toronto Law Journal, 65(3), 239-283. Retrieved from EBSCOhost, https://library.macewan.ca/full-record/edsjsr/edsjsr.24855483

Pushpanathan v. Canada (Minister of Citizenship and Immigration). (1998). 1 SCR 982 SCC 778. Retrieved from CanLII, https://canlii.ca/t/1fqs6

R. v. Ruzic. (2001). 1 SCR 687 SCC 24. Retrieved from CanLII, https://canlii.ca/t/520x

Rotman, L. I., \& Wydrzynski, C. (2008). "Life, Liberty, and Security of the Person." Constitutional Law: Cases, Commentary, and Principles (1103-1159), edited by Leonard I. Rotman, Bruce P. Elman, and Gerald L. Gall, Thomson Carswell. 


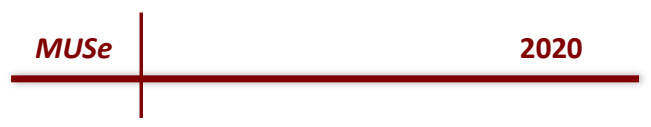

Said, W. E. (2006) "Political Asylum and Torture: A Comparative Analysis." Third World Quarterly, 27(5), 871-883. Retrieved from EBSCOhost, https://library.macewan.ca/fullrecord/edsjsr/edsjsr.4017783

Singh v. Minister of Employment and Immigration. (1985). 1 SCR 177 SCC 65. Retrieved from CanLII, https://canlii.ca/t/1fv22

Stewart, H. (2012). Fundamental Justice: section 7 of the Canadian Charter of Rights and Freedoms. Irwin Law.

Suresh v. Canada (Minister of Citizenship and Immigration). (2002). 1 SCR 3 SCC 1. Retrieved from CanLII, https://canlii.ca/t/51wf 